\title{
EKSISTENSI SELEKTOR TERUKUR PADA FUNGSI BERNILAI HIMPUNAN DI DALAM RUANG BANACH TAK SEPARABEL
}

\author{
Mohamad Muslikh \\ Jurusan Matematika F.MIPA Universitas Brawijaya \\ mslk@ub.ac.id, mslk59@yahoo.co.id
}

\begin{abstract}
In the Kuratowski-Ryll Nardzewski theorem, measurable selector of the setvalued functions exist if the value of set-valued function is a subset of a separable Banach spaces. In this article show that the set-valued function has a measurable selector in non separable Banach spaces.
\end{abstract}

Keywords: set valued function, measurable selector

ABSTRAK. Dalam Teorema Kuratowski-Ryll Nardzewski, selector terukur dari fungsi bernilai himpunan dijamin ada apabila daerah nilai fungsi bernilai himpunan merupakan himpunan bagian dari ruang Banach yang separabel. Pada artikel ini ditunjukkan bahwa fungsi bernilai himpunan mempunyai selektor terukur di dalam ruang Banach tak separabel.

Kata Kunci: fungsi bernilai himpunan, selektor terukur

\section{PENDAhULUAN}

Pengembangan teori eksistensi selektor terukur seringkali dikaitkan dengan kebutuhan aplikasi, seperti pada Teori Kontrol, inklusi diferensial, model matematika ekonomi dan pengintegralan fungsi bernilai himpunan. Khususnya dalam pengintegralan fungsi bernilai himpunan, para peneliti telah lama sekali mendambakan suatu teorema seleksi tanpa separabelitas. Selama ini, mereka bekerja dengan mengandalkan teorema Kuratowski - Ryll Nardzewski yang mana kita ketahui bahwa teorema tersebut hanya berlaku untuk kasus separabel saja. Dalam artikel ini persyaratan separable akan dihilangkan dan kemudian akan ditunjukkan adanya selektor terukur untuk fungsi bernilai himpunan dimana nilai-nilainya berupa himpunan tertutup terhadap ruang Banach tak separabel. 
Pekerjaan sejenis telah dihasilkan oleh Cascales dkk (Cascales, 2010), akan tetapi mereka mengambil nilai-nilainya berupa himpunan kompak lemah (weakly compact) di dalam ruang Banach tak separabel.

Pada artikel ini, notasi $X$ adalah ruang Banach real, pasangan $(\Omega, \Sigma, \mu)$ adalah ruang ukuran lengkap kecuali ada pemberitahuan tambahan. Untuk ruang Banach real $(X,\|\|$.$) dinotasikan B_{X}$ sebagai unit bola tertutup dan $S_{X}$ sebagai permukaan bola (sphere) satuan. Untuk himpunan $D \subset X$ didefinisikan diameter himpunan $D$ sebagai,

$$
\operatorname{diam}(D)=\sup _{x, y \in D}\|x-y\|
$$

Notasi $2^{X}$ adalah koleksi semua himpunan bagian tak kosong dari $X$. Sedangkan $\operatorname{cl}(X)$ adalah koleksi semua himpunan bagian tak kosong tertutup dari $X$ dan $k(X)$ koleksi semua himpunan bagian kompak tak kosong dari $X$. Pemetaan berbentuk $F: \Omega \rightarrow 2^{X}$ disebut fungsi bernilai himpunan yaitu fungsi yang nilainilainya berupa himpunan bagian tak kosong dari $X$. Fungsi (single valued ) $f: \Omega \rightarrow$ $X$ dikatakan selector dari $F$ jika untuk setiap $\omega \in \Omega, f(\omega) \in F(\omega)$.

Definisi 1.1. Diberikan ruang terukur $(\Omega, \Sigma)$ dan ruang Banach $X$ separabel. Fungsi bernilai himpunan $F: \Omega \rightarrow \operatorname{cl}(X)$ dikatakan terukur (measurable) jika untuk setiap himpunan terbuka $U \subset X$, prapeta $F^{-1}(U)=\{\omega \in \Omega \mid F(\omega) \cap U \neq \emptyset\} \in \Sigma$.

Keterukuran set valued function $F$ yang demikian sering kali disebut terukur Effros (Effros measurable) [Cascales, 2010]. Jika selection $f$ dari $F$ terukur, maka $f$ disebut selection terukur dari $F$.

Teorema eksistensi selektor terukur dari suatu fungsi bernilai himpunan pertama kali diperkenalkan oleh K. Kuratowski dan C. Ryll Nardzewski. Berikut teorema yang dimaksud. 
Teorema 1.2. (Kuratowski-Ryll Nardzewski, 1965). Diberikan ruang terukur $(\Omega, \Sigma)$ dan ruang Banach $X$ separabel. Jika fungsi bernilai himpunan $F: \Omega \rightarrow \operatorname{cl}(X)$ terukur Effros, maka $F$ memuat selektor terukur $f$.

Teorema 1.2. di atas, menjadi perhatian kami. Apakah dengan menghilangkan pembatas separabilitas pada daerah nilainya, eksistensi selektor terukur masih berlaku? Baiklah terlebih dahulu kita tinjau hasil-hasil berikut.

Untuk fungsi bernilai himpunan $F$ yang terukur Effros dengan nilai-nilai $F$ tertutup di dalam ruang Banach separabel, dapat dikarakterisasikan sebagai berikut:

Teorema 1.3. (Castaing dan Validier, 1977). Diberikan $(\Omega, \Sigma, \mu)$ ruang ukuran lengkap, ruang Banach X separabel dan fungsi bernilai himpunan $F: \Omega \rightarrow \operatorname{cl}(X)$. Maka pernyataan berikut ekuivalen

(i) F terukur Effros

(ii) Terdapat barisan selektor terukur $f_{n}: \Omega \rightarrow X$ dari $F$ untuk setiap $n \in \mathbb{N}$ sedemikian sehingga untuk setiap $\omega \in \Omega$ berlaku $F(\omega)=\operatorname{cl}\left\{f_{n}(\omega)\right\}$

Pernyataan bagian (ii) di atas dikenal sebagai representasi Castaing.

Fungsi $f: \Omega \rightarrow X$ dikatakan terukur kuat (strongly measurable) jika terdapat barisan fungsi sederhana $\varphi_{n}: \Omega \rightarrow X$ sedemikian sehingga $f=\lim _{n} \varphi_{n}(\mu-a . e)$. Jika ruang Banach $X$ separabel dan fungsi bernilai himpunan $F: \Omega \rightarrow \operatorname{cl}(X)$ terukur Effros, maka $F$ memuat selektor-selektor terukur kuat, sebab dengan menggunakan teorema Kuratowski - Ryll Nardzewski, akan diperoleh selektor terukur $f$ dari $F$. Kemudian dengan bantuan teorema keterukuran dari Pettis [Diestel dan Uhl 1977] disimpulkan selektor $f$ terukur kuat. 


\section{FUNGSI BERNILAI HIMPUNAN YANG MEMUAT SELEKTOR TERUKUR KUAT.}

Dalam bagian pertama ini disajikan fungsi bernilai himpunan yang mempunyai selektor - selektor terukur kuat dalam kontek ruang Banach separabel. Dimisalkan koleksi $\Sigma^{+}=\{A \in \Sigma \mid \mu(A)>0\}$ dan koleksi $\sum_{A}^{+}=\left\{B \subset A \mid A \in \Sigma^{+}\right\}$. Selanjutnya kita perhatikan definisi berikut

\section{Definisi 2.1.}

Fungsi bernilai himpunan $F: \Omega \rightarrow 2^{X}$ dikatakan mempunyai sifat (P), jika untuk setiap $\epsilon>0$ dan setiap $A \in \Sigma^{+}$terdapat himpunan $B \in \sum_{A}^{+}$dan $D \subset X$ dengan $\operatorname{diam}(D) \leq \epsilon$ sedemikian sehingga $F(\omega) \cap D \neq \varnothing$ untuk setiap $\omega \in B$.

Dalam hal fungsi saja, sifat (P) sebagaimana pada Definisi 2.1. merupakan karakterisasi lain dari fungsi-fungsi yang terukur kuat. Berikut proposisi yang menyatakan hal tersebut.

Proposisi 2.2.. (Cascales, 2010)Untuk fungsi $f: \Omega \rightarrow X$, maka pernyataan berikut ekuivalen

(i) Fungsi $f$ memenuhi sifat $(P)$.

(ii) Untuk setiap $\epsilon>0$ dan setiap $A \in \sum^{+}$terdapat himpunan $B \in \sum_{A}^{+}$dengan $\operatorname{diam}(f(B)) \leq \epsilon$.

(iii) Fungsi $f$ terukur kuat.

Sedangkan hubungannya dengan fungsi bernilai himpunan disajikan sebagai berikut.

Proposisi 2.3. (Cascales, 2010). Dimisalkan fungsi bernilai himpunan $F: \Omega \rightarrow 2^{X}$.

(i) Jika ada fungsi bernilai himpunan $G: \Omega \rightarrow 2^{X}$ yang memenuhi sifat $(P)$ sedemikian sehingga $G(\omega) \subset F(\omega) \mu$-a.e. untuk $\omega \in \Omega$, maka $F$ juga memenuhi sifat $(P)$. 
(ii) Jika F memuat selektor-selektor terukur kuat, maka F memenuhi sifat (P)

Di sini dapat kita simpulkan bahwa, jika $X$ separabel dan fungsi bernilai himpunan $F: \Omega \rightarrow \operatorname{cl}(X)$ terukur Effros, maka $F$ mempunyai sifat $(\mathrm{P})$, sebab $F$ memuat selektor terukur kuat sebagaimana telah diuraikan pada bagian pendahuluan. Dengan demikian berdasarkan Proposisi 2.3 bagian (ii), maka kesimpulan di atas benar. Sebaliknya belum tentu berlaku, yaitu ada fungsi bernilai himpunan yang mempunyai sifat $(\mathrm{P})$ namun tidak terukur Effros. Sebagai contoh sederhana dapat kita ambil fungsi bernilai himpunan $F:[0,1] \rightarrow k(\mathbb{R})$ yang didefinisikan sebagai $F(t)=$ $[0, h(t)]$, dengan fungsi $h:[0,1] \rightarrow \mathbb{R}^{+}$tidak terukur. Nampak bahwa $F$ mempunyai selector terukur $f=0 \in F$ dan tentu $F$ mempunyai sifat (P), akan tetapi $F$ tidak terukur Effros, sebab untuk setiap $\alpha \in \mathbb{R}$, himpunan

$$
\begin{aligned}
F^{-1}((\alpha,+\infty)) & =\{t \in[0,1] \mid F(t) \cap(\alpha,+\infty) \neq \emptyset\} \\
& =\{t \in[0,1] \mid h(t)>\alpha\}
\end{aligned}
$$

Sekarang akan kita tinjau hasil-hasil eksistensi selector terukur yang telah dikerjakan oleh penulis lain dalam kontek ruang Banach tak separabel. B. Cascales dan kawan-kawan dalam artikelnya [ Cascales, 2010] menyatakan hasilnya sebagai berikut.

Teorema 2.4. Dimisalkan $(\Omega, \Sigma, \mu)$ ruang ukuran lengkap, ruang Banach $X$ tak separabel dan fungsi bernilai himpunan $F: \Omega \rightarrow w k(X)$, dimana wk(X) koleksi semua hipunan bagian tak kosong yang kompak lemah dari X. Maka pernyataan berikut ekivalen

(i) F memuat selektor yang terukur kuat.

(ii) F memenuhi sifat $(P)$.

(iii) Terdapat himpunan $\Omega_{0} \in \Sigma$ dengan $\mu\left(\Omega_{0}\right)=0$, sub ruang separabel $Y \subset X$ dan fungsi bernilai himpunan $G: \Omega \backslash \Omega_{0} \rightarrow w k(Y)$ yang terukur Effros sedemikian sehingga $G(\omega) \subset F(\omega)$ untuk setiap $\omega \in\left(\Omega \backslash \Omega_{0}\right)$. 
Bukti Teorema 2.4 dapat dibaca dalam [Cascales, 2010].

Berikutnya, D. Barcenas dan W.Urbina [Barcenas, 1997) memperkenalkan Definisi fungsi bernilai himpunan terukur di dalam ruang Banach tak separabel. Definisi tepatnya sebagai berikut.

\section{Definisi 2.5.}

Dimisalkan $(\Omega, \Sigma, \mu)$ ruang ukuran lengkap dan ruang Banach $X$ tak separabel. Fungsi bernilai himpunan $F: \Omega \rightarrow \operatorname{cl}(X)$ dikatakan terukur $-\mu$, jika terdapat barisan fungsi terukur- $\mu f_{n}: \Omega \rightarrow X$ dan himpunan $\Omega_{0} \in \Sigma$ dengan $\mu\left(\Omega_{0}\right)=0$ maka berlaku

$$
F(\omega)=\operatorname{cl}\left\{f_{n}(\omega)\right\}, \quad \forall \omega \in\left(\Omega \backslash \Omega_{0}\right)
$$

Definisi ini mirip dengan karakterisasi fungsi bernilai himpunan yang terukur dalam pengertian Effros ( lihat Teorema 1.3 ). Hanya saja definisi di atas, mengabaikan nilai-nilai $F$ pada himpunan yang berukuran nol. Dengan Definisi tersebut, D. Barcenas dan W. Urbina mengkarakterisasikan fungsi bernilai himpunan $F: \Omega \rightarrow \operatorname{cl}(X)$ terukur dalam pengertian Definisi 2.5 sebagai berikut.

Teorema 2.6. (Barcenas dan Ubrina, 1997). Diberikan X ruang Banach tak separabel, $(\Omega, \Sigma, \mu)$ ruang terukur yang lengkap dengan ukuran berhingga dan fungsi bernilai himpunan $F: \Omega \longrightarrow c l(X)$. Maka pernyataan di bawah ini ekivalen

(i) F terukur dalam pengertian Definisi 2.5.

(ii) Terdapat $\Omega_{0} \in \Sigma$ dengan $\mu\left(\Omega_{0}\right)=0$ sedemikian sehingga ruang bagian tertutup $Y=\left[\mathrm{U}_{\omega \in \Omega \backslash \Omega_{0}} F(\omega)\right]$ yang dibangkitkan oleh $\mathrm{U}_{\omega \in \Omega \backslash \Omega_{0}} F(\omega)$ separabel dan untuk setiap himpunan terbuka $U \subset Y, F^{-1}(U) \in \Sigma$.

Bukti Teorema 2.6 dapat dibaca dalam artikelnya [Barcenas, 1997]. 
Berikut ini adalah hasil utama dalam artikel ini.

Teorema 2.7. Diberikan $X$ ruang Banach tak separabel dan $(\Omega, \Sigma, \mu)$ ruang ukuran lengkap . Jika fungsi bernilai himpunan $F: \Omega \rightarrow c l(X)$ terukur dalam pengertian Definisi 2.5, maka F memuat selektor terukur kuat.

Bukti.

Karena $F$ terukur dalam pengertian Definisi 2.5, maka menurut Teorema 2.6 , terdapat $\Omega_{0} \in \Sigma$ dengan $\mu\left(\Omega_{0}\right)=0$ sedemikian sehingga ruang bagian tertutup $Y=$ $\left[\mathrm{U}_{\omega \in \Omega \backslash \Omega_{0}} F(\omega)\right] \subset X$ dan $Y$ separable. Definisikan fungsi bernilai himpunan $G: \Omega \rightarrow \operatorname{cl}(Y)$ dengan

$$
G(\omega)=\left\{\begin{array}{c}
F(\omega), \text { jika } \omega \in\left(\Omega \backslash \Omega_{0}\right) \\
\{0\}, \quad \text { jika } \omega \in \Omega_{0}
\end{array}\right.
$$

dan fungsi $g_{n}: \Omega \rightarrow X$ dengan

$$
g_{n}(\omega)=\left\{\begin{array}{cl}
f_{n}(\omega), & \text { jika } \omega \in\left(\Omega \backslash \Omega_{0}\right), \\
0, & \text { jika } \omega \in \Omega_{0},
\end{array}\right.
$$

Dimana $f_{n}: \Omega \rightarrow X$ barisan fungsi terukur sedemikian sehingga

$$
F(\omega)=\operatorname{cl}\left\{f_{n}(\omega)\right\}, \forall \omega \in\left(\Omega \backslash \Omega_{0}\right) .
$$

Karena $\mu$ lengkap, maka setiap $g_{n}$ terukur dan

$$
G(\omega)=\operatorname{cl}\left\{g_{n}(\omega)\right\}, \forall \omega \in \Omega .
$$

Karena $Y$ separabel, maka menurut Teorema 1.3, fungsi bernilai himpunan $G$ terukur Effros, sehingga $G$ memuat selektor terukur kuat sebagaimana yang dijelaskan pada pendahuluan. Karena itu, $F$ memuat selektor terukur kuat.

\section{KESIMPULAN DAN SARAN}

Dari hasil utama yang diperoleh, dapat disimpulkan bahwa Teorema Kuratowski-Ryll Nardzewski masih berlaku tanpa pembatasan separabilitas pada daerah ruang nilainya. Kesimpulan yang kedua adalah, fungsi bernilai himpunan $F: \Omega \rightarrow \operatorname{cl}(X)$ yang terukur dalam pengertian Definisi 2.5. mempunyai sifat $(\mathrm{P})$ 
(lihat Proposisi 2.3.). Adapun saran yang bisa kami berikan dalam artikel ini adalah mengembangkan hasil pada Teorema 2.7, untuk fungsi bernilai himpunan $F$ yang nilai-nilainya di dalam $k(X)$.

\section{UCAPAN TERIMA KASIH}

Disampaikan ucapan terima kasih kepada DP2M Dirjen Dikti Kementerian Pendidikan dan Kebudayaan RI yang telah memberikan dana untuk mendukung pelaksanaan Penelitian Fundamental dengan nomor kontrak 0636/02304.2.16/15/2011R dan 121/D3/PL/2011.

\section{DAFTAR PUSTAKA}

Aubin, J. P. dan Franskowska, H (1990) Set-Valued Analysis, Birkhauser, Boston.

Barcenas, D. dan Urbina, W. (1997) Measurable Multifunctions in Nonseparable Banach spaces, SIAM J. Math. Anal, Vol. 28, No. 511(1), 1212-1226.

Cascales, B., Kadets, V. dan Rodriguez, J. (2010) Measurability and Selections of Multi-functons in Banach spaces, Journal of Convex Analysis, 17. No.1, 229240.

Castaing, C. dan Valadier, M. (1977) Convex Analysis Measurable Multifunctions, Lecture Notes in Math. 580, Springer -Verlag, Berlin.

Diestel, J. and Uhl, J.J. Jr. (1977)., Vektor Measure, American Mathematical Society, Providence, R.I No. 15.

Kuratowski, K. dan Ryll-Nardzewski, C. (1965) A General Theorem on Selectors, Bull. Acad. Polon. Sci. Ser. Sci. Math. Astronom. Phys. 13, 397- 403. 